\title{
Expression of $\mathrm{Na}^{+} /$glucose co-transporter 1 (SGLT1) is enhanced by supplementation of the diet of weaning piglets with artificial sweeteners
}

\author{
Andrew W. Moran ${ }^{1} \dagger$, Miran A. Al-Rammahi ${ }^{1} \dagger$, Daleep K. Arora ${ }^{1}$, Daniel J. Batchelor ${ }^{1}$, Erin A. Coulter ${ }^{1}$, \\ Kristian Daly ${ }^{1}$, Catherine Ionescu ${ }^{2}$, David Bravo ${ }^{2}$ and Soraya P. Shirazi-Beechey ${ }^{1 *}$ \\ ${ }^{1}$ Epithelial Function and Development Group, Department of Veterinary Preclinical Sciences, University of Liverpool, \\ Liverpool, $U K$ \\ ${ }^{2}$ Pancosma SA, Geneva, Switzerland
}

(Received 7 October 2009 - Revised 27 January 2010 - Accepted 8 February 2010 - First published online 26 March 2010)

In an intensive livestock production, a shorter suckling period allows more piglets to be born. However, this practice leads to a number of disorders including nutrient malabsorption, resulting in diarrhoea, malnutrition and dehydration. A number of strategies have been proposed to overcome weaning problems. Artificial sweeteners, routinely included in piglets' diet, were thought to enhance feed palatability. However, it is shown in rodent models that when included in the diet, they enhance the expression of $\mathrm{Na}^{+} /$glucose co-transporter (SGLT1) and the capacity of the gut to absorb glucose. Here, we show that supplementation of piglets' feed with a combination of artificial sweeteners saccharin and neohesperidin dihydrochalcone enhances the expression of SGLT1 and intestinal glucose transport function. Artificial sweeteners are known to act on the intestinal sweet taste receptor T1R2/T1R3 and its partner G-protein, gustducin, to activate pathways leading to SGLT1 up-regulation. Here, we demonstrate that T1R2, T1R3 and gustducin are expressed together in the enteroendocrine cells of piglet intestine. Furthermore, gut hormones secreted by the endocrine cells in response to dietary carbohydrates, glucagon-like peptides (GLP)-1, GLP-2 and glucose-dependent insulinotrophic peptide (GIP), are co-expressed with type 1 G-protein-coupled receptors (T1R) and gustducin, indicating that L- and K-enteroendocrine cells express these taste elements. In a fewer endocrine cells, T1R are also co-expressed with serotonin. Lactisole, an inhibitor of human T1R3, had no inhibitory effect on sweetener-induced SGLT1 up-regulation in piglet intestine. A better understanding of the mechanism(s) involved in sweetener up-regulation of SGLT1 will allow the identification of nutritional targets with implications for the prevention of weaning-related malabsorption.

$\mathrm{Na}^{+}$/glucose co-transporter 1: Sweet taste receptors: Intestine: Artificial sweeteners: Weaned piglets

In nature, weaning in pigs is a gradual process that occurs at approximately 3 months of age when there is a change in the diet from mother's milk to solid food. However, in today's intensive animal production, piglets are weaned at $3-4$ weeks of age or even as early as $16 \mathrm{~d}$ of age ${ }^{(1)}$. While this practice results in increased number of piglets born per year, weaning disorders are one of the most important problems in the pig industry ${ }^{(1,2)}$. It has been shown that early weaning has a deleterious impact on piglets' intestinal function, leading to nutrient malabsorption, diarrhoea, malnutrition and dehydration ${ }^{(3,4)}$. A combination of artificial sweeteners, saccharin and neohesperidin dihydrochalcone (NHDC, trade name Sucram), is routinely included in the commercial feed of piglets. Saccharin and NHDC are the only artificial sweeteners approved so far to be included in the animal feed ${ }^{(5)}$. NHDC is a semi-natural sweetener that blocks the bitterness of saccharin. While it has been shown that inclusion of Sucram in the piglets' feed may be effective in avoiding post-weaning enteric disorders and enhancing the growth performance of early weaned piglets ${ }^{(6)}$, the molecular basis of the effect is unknown.

We have shown previously that the heterodimeric sweet taste receptor comprising $\mathrm{T} 1 \mathrm{R} 2+\mathrm{T} 1 \mathrm{R} 3$ is expressed in mouse and human intestinal enteroendocrine cells ${ }^{(7)}$. Furthermore, we have determined that dietary glucose and artificial sweeteners act on the intestinal sweet taste receptor and its coupled G-protein, gustducin, to elicit the up-regulation of $\mathrm{Na}^{+}$/glucose co-transporter 1 (SGLT1) ${ }^{(8,9)}$. Our previous in vivo studies in mouse intestine showed that only those artificial sweeteners that activated mouse lingual epithelium sweet taste receptor led to the up-regulation of intestinal SGLT1 ${ }^{(8)}$.

In the present paper, using immunohistochemistry, we first determined that T1R2, T1R3, gustducin, chromogranin A and gut hormones secreted in response to dietary carbohydrate (CHO), glucagon-like peptides-1 and -2 (GLP-1 and GLP-2), glucose-dependent insulinotrophic peptide (GIP) and serotonin are co-expressed in subsets of intestinal enteroendocrine cells.

Abbreviations: CHO, carbohydrate; G $\alpha_{\text {gust }}, \alpha$-subunit of G-protein gustducin; GIP, glucose-dependent insulinotrophic peptide; GLP, glucagon-like peptide; NHDC, neohesperidin dihydrochalcone; SGLT1, $\mathrm{Na}^{+} /$glucose co-transporter 1; T1R, type 1 G-protein-coupled receptors.

* Corresponding author: Professor Soraya P. Shirazi-Beechey, fax +440151 794 4244, email spsb@liverpool.ac.uk

$\dagger$ A. W. M. and M. A. A.-R. have contributed equally. 
This supports our previous finding in mouse and human intestine that the sweet taste receptor is expressed only in enteroendocrine cells and not in any other intestinal epithelial cells.

Furthermore, we demonstrated that there was a significant up-regulation of SGLT1 expression at the levels of mRNA, protein and function in the intestine of 28-d-old piglets when weaned onto commercial wheat- and soya-based swine diet containing Sucram compared with the same diet lacking Sucram. Addition of saccharin and NHDC, individually or together, to the drinking-water of the piglets also resulted in the same magnitude of SGLT1 up-regulation. The data indicate that inclusion of artificial sweeteners enhances the capacity of the piglet intestine to absorb dietary sugars, and that there is no synergistic effect in combining saccharin and NHDC.

Analysis of the gustatory behaviour of pigs towards a number of artificial sweeteners which taste sweet to human subjects has led to the proposal that pigs can taste sodium saccharin, but may not taste $\mathrm{NHDC}^{(10)}$. However, comparison of swine T1R3 amino acid sequence with that of human and mice (the latter cannot taste NHDC) indicates that interactive residues for NHDC in pig T1R3 resemble those in human. In contrast, comparable residues critical for the inhibition of human T1R3 by the sweet taste inhibitor lactisole in pigs resemble those in mice which are insensitive to lactisole ${ }^{(11)}$.

The design of new sweeteners therefore requires a good knowledge of structural and sequential variations of the sweet taste receptor in different species. This will facilitate the appropriate use of sweeteners to enhance not only sweet sensation, but also intestinal nutrient absorption with the attendant potential of preventing post-weaning malabsorption.

\section{Methods}

\section{Pigs, diets and tissue collection}

Male and female suckling Landrace $\times$ Large White pigs aged $28 \mathrm{~d}$ were placed in pairs into standard pens measuring $1.5 \mathrm{~m} \times 1.5 \mathrm{~m}$ in a room with continuous heating $\left(26.7^{\circ} \mathrm{C} /\right.$ $80^{\circ} \mathrm{F}$ ) and $12 \mathrm{~h}$ light and dark cycle. To avoid any dietary contribution from the bedding, dust-extracted wood shavings were used. They were weaned to and maintained on the following isoenergetic, $15.7495 \mathrm{~kJ} / \mathrm{g}$, diets for $3 \mathrm{~d}$ : group 1 consisting of sixteen piglets was fed a commercial wheat- and soyabased swine diet (Target Feeds Limited, Whitchurch, UK) containing $43 \%$ digestible $\mathrm{CHO}$; group 2 consisting of twelve piglets was fed the same diet, but it contained Sucram $(150 \mathrm{mg} / \mathrm{kg}$ body weight), which consists of artificial sweeteners, saccharin $(120 \mathrm{mg} / \mathrm{kg}$ of feed) and NHDC (30 mg/kg of feed); group 3 consisting of eight piglets was fed $43 \%$ CHO diet, but saccharin and NHDC were included in the drinking-water in such a way that the final concentration of these sweeteners was similar to that in the diet of group 2; group 4 consisting of eight piglets was maintained on $43 \%$ CHO diet with $34.8 \mathrm{mg} / \mathrm{d}$ per animal (final concentration $=0.25 \mathrm{mM}$ ) of saccharin; group 5 consisting of eight piglets was maintained on $43 \% \mathrm{CHO}$ diet with $8.7 \mathrm{mg} / \mathrm{d}$ per animal (final concentration $=0.02 \mathrm{~mm}$ ) of NHDC included in the drinking-water; and group 6 consisting of four piglets was fed the commercial diet containing Sucram with lactisole, the specific inhibitor of human sweet taste receptor ${ }^{(11)}$, the latter was included in the drinking-water. The animals remained healthy throughout the experiment, and had no sign of enteric disturbances.

After $3 \mathrm{~d}$, piglets were killed with an intravenous injection of $20 \mathrm{ml}$ pentobarbitone $(200 \mathrm{mg} / \mathrm{ml}$ Pentoject; AnimalCare Limited, Dunnington, York, UK) to the cranial vena cava (in line with the UK Home Office Schedule 1 regulation). Immediately, sections of the small intestine that were approximately $40 \mathrm{~cm}$ in length were removed from proximal (distal to the gastric pylorus), mid (half way along the small intestine) and distal (proximal to the ileocaecal junction) small intestine. Intestinal sections were everted, rinsed with ice-cold saline and wrapped in Al foil before freezing in liquid nitrogen. Upon returning to the laboratory, tissues were stored at $-80^{\circ} \mathrm{C}$ until use.

\section{Isolation of brush-border membrane vesicles}

Isolation of brush-border membrane vesicles was performed as described by Shirazi-Beechey et al. ${ }^{(12)}$. All steps were carried out at $4^{\circ} \mathrm{C}$. The procedure is identical to that described in the preceding paper $^{(13)}$.

\section{Transport studies}

Glucose transport was assayed as described by Dyer et al. ${ }^{(14)}$, and it was based on the method of Shirazi-Beechey et al. ${ }^{(12)}$. Brush-border membrane vesicles $(100 \mu \mathrm{g})$ were incubated at $38^{\circ} \mathrm{C}$ for $1 \mathrm{~min}$. The reaction was started with the addition of $100 \mu \mathrm{l}$ of incubation medium containing $100 \mathrm{mM}-\mathrm{NaSCN}$ (or KSCN), $100 \mathrm{~mm}$-mannitol, $20 \mathrm{mM}$-HEPES/Tris (pH 7.4),

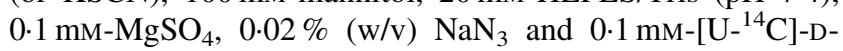
glucose. The reaction was stopped after $3 \mathrm{~s}$ by the addition of $1 \mathrm{ml}$ of ice-cold stop buffer containing $150 \mathrm{mM}-\mathrm{KCl}$, 20 mM-HEPES/Tris (pH 7.4), 0.1 mM-MgSO $4,0.02 \%$ (w/v) $\mathrm{NaN}_{3}$ and $0.1 \mathrm{~mm}$-phlorizin. A $0.9 \mathrm{ml}$ fraction was removed and filtered rapidly on $0.22 \mu \mathrm{m}$ pore cellulose acetate/nitrate filter (GSTF02500; Millipore, Watford, Herts, UK). The filter was washed five times with $1 \mathrm{ml}$ of ice-cold stop buffer, and the radioactivity retained on the filter was measured by liquid scintillation counting. All uptakes were performed in triplicate.

\section{Western blotting}

Western blotting was performed as described previously by Dyer et al. ${ }^{(15,16)}$ using antibodies to SGLT1 (custom synthesis) and $\beta$-actin ${ }^{(15-17)}$ (clone AC-15; Sigma-Aldrich Ltd, Poole, Dorset, UK). Visualisation of immunoreactive bands was performed with horseradish peroxide-conjugated secondary antibodies (DAKO Limited, Ely, Cambridge, UK) and enhanced chemiluminescence (GE Healthcare, Little Chalfont, Bucks, UK). Quantification of the immunoreactive bands using scanning densitometry was performed using Phoretix 1D software (Non-linear Dynamics, Newcastle-upon-Tyne, UK).

\section{Quantitative PCR}

Quantitative PCR was performed for the amplification of SGLT1 (accession no.: M34044; forward 5'-AAAGGAGAGGTCTGGGATGGTAA-3', reverse 5'-ATTTCCCTAGTGGCCTGAGATTG- $3^{\prime}$ ) and $\beta$-actin (accession no.: DQ452569; 
forward 5'-CGAGGCCCAGAGCAAGAG-3', reverse 5'-TCCATGTCGTCCCAGTTGGT- $3^{\prime}$ ). RNA isolation, complementary DNA synthesis and quantitative PCR were carried out as described previously ${ }^{(16)}$. All the reactions were performed in triplicate on a Rotor-Gene 3000 (Qiagen Limited, Crawley, West Sussex, UK) with relative amounts of SGLT1 mRNA normalised to $\beta$-actin within each sample.

\section{Immunohistochemical localisation of taste receptors and gut hormones}

Immediately after euthanasia, sections of small intestine collected from proximal, mid and distal regions were fixed in $4 \%(\mathrm{w} / \mathrm{v})$ paraformaldehyde in PBS for $4 \mathrm{~h}$. Subsequently, they were placed in $20 \%$ (w/v) sucrose (Fluka, Gillingham, UK) in PBS. Afterwards, tissue samples were gelatin embedded and frozen in liquid nitrogen-cooled isopentane before sectioning on a cryostat (Bright, Huntingdon, Cambs, UK). Ten-micrometre-thick serial sections thaw-mounted onto polylysine-coated slides were washed for $5 \times 5 \mathrm{~min}$ in PBS before non-specific binding sites were blocked using antibody-specific blocking solutions for $1 \mathrm{~h}$ at room temperature. For procedures using antibodies to T1R2, T1R3 and gustducin, blocking solution containing $5 \%(\mathrm{w} / \mathrm{v})$ sucrose, $3 \%(\mathrm{w} / \mathrm{v})$ bovine serum albumin, $2 \%(\mathrm{v} / \mathrm{v})$ donkey serum and $0.1 \%$ $(\mathrm{w} / \mathrm{v}) \mathrm{NaN}_{3}$ in PBS was used. When using antibodies to either GLP-1, GLP-2, GIP or serotonin, the blocking solution consisted of $3 \%(\mathrm{w} / \mathrm{v})$ bovine serum albumin, $2 \%(\mathrm{v} / \mathrm{v})$ donkey serum and $0.1 \%(\mathrm{w} / \mathrm{v}) \mathrm{NaN}_{3}$ in $\mathrm{PBS}$, and when using antibodies to SGLT1 and chromogranin A, the blocking solution contained $10 \%(\mathrm{v} / \mathrm{v})$ donkey serum in PBS.

A number of primary antibodies raised in different species were used for single and double immunolabelling. They consisted of a polyclonal antibody to chromogranin A (ab8205), a polyclonal antibody to serotonin (ab3439), both raised in rabbits, and monoclonal antibodies to human chromogranin A (ab8204); all were purchased from Abcam Limited (Cambridge, UK) and were diluted 1:100. The antibody to SGLT1 was raised (custom synthesis) in rabbits against a synthetic peptide corresponding to amino acids 402-420 (STLFTMDIYTKIRKKASEK), a conserved intracellular loop of SGLT1 ${ }^{(16)}$ sharing $93.1 \%$ identity to swine SGLT1, used at a dilution of 1:100. This SGLT1 antibody was also used in Western blotting (see above). Antibodies to T1R2 (H-90) and T1R3 (H-145) were raised in rabbits, while antibodies to T1R2 (T-20) and T1R3 (N-20) were raised in goats. They were obtained from Santa Cruz Biotechnology (Calne, UK) and were used at a dilution of 1:750. The antibody to $\alpha$-gustducin (kindly provided by Professor R. F. Margolskee, Monell Chemical Senses Center, Philadelphia, PA, USA) was raised in rabbits, and it was used at a dilution of 1:300. Antibodies to GIP (Y-20), GLP-1 (C-17) and GLP-2 (C-20) used at a dilusion of 1:100 were all raised in goat, and they were purchased from Santa Cruz Biotechnology. (a)
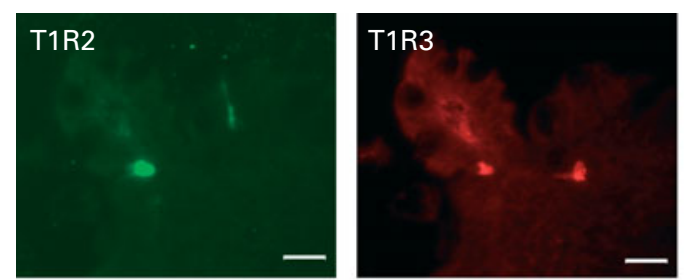

(b)

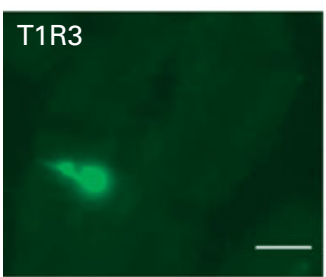

(c)

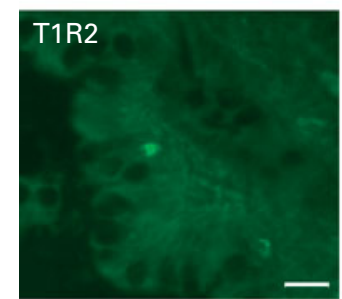

(d)

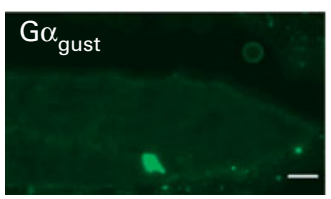

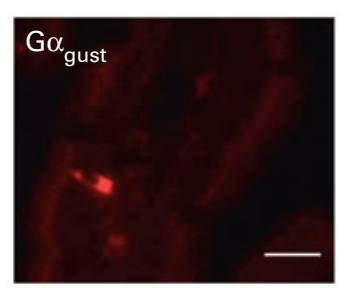
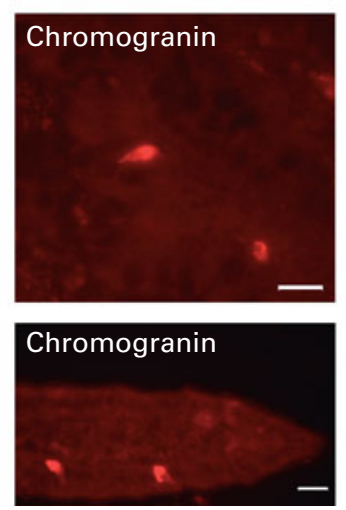
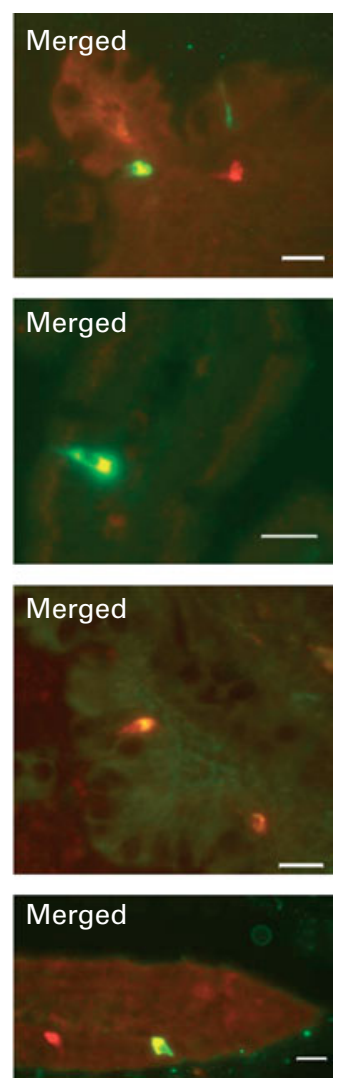

Fig. 1. Detection and localisation of $T 1 R 2, T 1 R 3, \alpha$-subunit of $G$-protein gustducin $\left(G \alpha_{\text {gust }}\right)$ and chromogranin $A$ along crypt-villus axis of swine small intestine. Serial frozen sections of piglet mid-small intestine were used for immunofluorescence detection of (a) T1R2 (green) and T1R3 (red); (b) T1R3 (green) and G $\alpha_{\text {gust }}$ (red); (c) T1R2 (green) and chromogranin (red); (d) $\mathrm{G} \alpha_{\text {gust }}$ (green) and chromogranin (red). Magnification for images (a) $-(\mathrm{c})$ is $200 \times$, and that for image (d) is $400 \times$. Scale bar represents $10 \mu \mathrm{m}$. 
For double immunostaining, tissues were incubated at $4{ }^{\circ} \mathrm{C}$ overnight with primary antibodies raised in different species. Antibodies were mixed with one another without changing the required final concentration. Following incubation with primary antibodies, slides were washed with PBS followed by staining the sections using fluorochrome-labelled antibodies. $\mathrm{Cy} 3$ - or fluorescein isothiocyanate-conjugated IgG secondary antibodies (Stratech Scientific Limited, Suffolk, UK) were used at a dilution of 1:500 with a $1 \mathrm{~h}$ incubation at room temperature. Sections were washed thoroughly with PBS as described earlier before mounting with Vectashield Hard mounting medium (Vector Laboratories Limited, Peterborough, UK). The sections were visualised using an epifluorescence microscope (Nikon, Kingston upon Thames, Surrey, UK), and images were captured with a Hamamatsu digital camera (C4742-96-12G04, Hamamatsu Photonics K.K., Hamamatsu City, Japan). Images from serial sections were merged using Imaging Products Laboratory imaging software (Nikon).

\section{Quantitative immunofluorescence of $\mathrm{Na}^{+} /$glucose co-transporter 1}

Immounofluorescent images were captured using Imaging Products Laboratory software (Nikon) and stored as 16-bit Tiff files, with quantitative analysis being carried out using MetaMorph (MDS Analytical Technologies Limited, Wokingham, Berks, UK), as described in the preceding paper ${ }^{(13)}$.

\section{Statistical analysis}

Results are expressed as means with their standard errors as indicated. Data were analysed using an unpaired two-tailed Student's $t$ test (GraphPad Prism 5; GraphPad Software, Inc., La Jolla, CA, USA). Results were considered significant if $P<0.05$.

\section{Ethical approval}

National/institutional guidelines for the care and use of animals were followed, and all the experiments were approved by the University of Liverpool Ethics Committee.

\section{Results}

Immunofluorescence detection and co-localisation of T1R2, T1R3, gustducin and glucose-responsive gut hormones in swine small intestine

Using immunohistochemistry, we have shown that the sweet taste receptor subunits, T1R2, T1R3 and the $\alpha$-subunit of G-protein gustducin $\left(\mathrm{G} \alpha_{\text {gust }}\right)$ are expressed only in a subpopulation of cells along the crypt-villus axis in piglet intestine (Figs. 1 and 2). In contrast, SGLT1 protein is expressed on the luminal membrane of all cells (absorptive enterocytes as well as enteroendocrine cells) along the villus (Fig. 2). There was negligible expression of T1R2, T1R3, G $\alpha_{\text {gust }}$ and SGLT1 in the crypts.

To investigate the potential co-localisation of T1R2, T1R3 and $\mathrm{G} \alpha_{\text {gust }}$, we used serial sections of frozen mid-small intestine (Fig. 1). All T1R3-expressing cells also expressed $\mathrm{G} \alpha_{\text {gust }}$ (Fig. 1(b)). Many, but not all, T1R3-expressing cells possessed
T1R2 (Fig. 1(a)). Omission of the primary antibodies for T1R2, T1R3 or gustducin showed that there was no nonspecific immunoreactivity (data not shown). The cells that contained type 1 G-protein-coupled receptors (T1R) and $\mathrm{G} \alpha_{\text {gust }}$ appear to be either triangular or flask-like in shape, suggesting that they are of enteroendocrine lineage. Immunohistochemistry of serial sections showed that the endocrine cell marker chromogranin A was indeed expressed with T1R and $\mathrm{G} \alpha_{\text {gust }}$ (Fig. 1(c) and (d)). However, not all chromogranin A-containing cells expressed $\mathrm{T} 1 \mathrm{R}$ and $\mathrm{G} \alpha_{\text {gust }}$ (Fig. 1(c) and (d)). Immunodetection methods also demonstrated that in the piglet small intestine, GIP, GLP-1, GLP-2 and serotonin are expressed in a subset of epithelial cells along the cryptvillus axis (Fig. 3(a) $-(\mathrm{g})$ ). The profile of expression of these gut hormones along the longitudinal axes of the intestine was proximal $>$ mid $>$ distal for GIP, and distal $>$ mid $>$ proximal for GLP-1 and GLP-2 (data not shown).

To investigate any association between the sweet taste receptor subunits and glucose-responsive gut hormones, serial sections of either frozen proximal, mid or the distal small intestine, as appropriate, were used. All cells expressing T1R2 also possessed GIP, GLP-1, GLP-2 and serotonin (Fig. 3(d)-(g)). The majority of the T1R3-expressing cells also expressed GLP-1, GLP-2 and GIP (Fig. 3(a)-(c)). The number of enteroendocrine cells co-expressing T1R and serotonin were far and few compared with the cells possessing T1R with GLP-1, GLP-2 and GIP (10 v. $50 \%$, respectively).

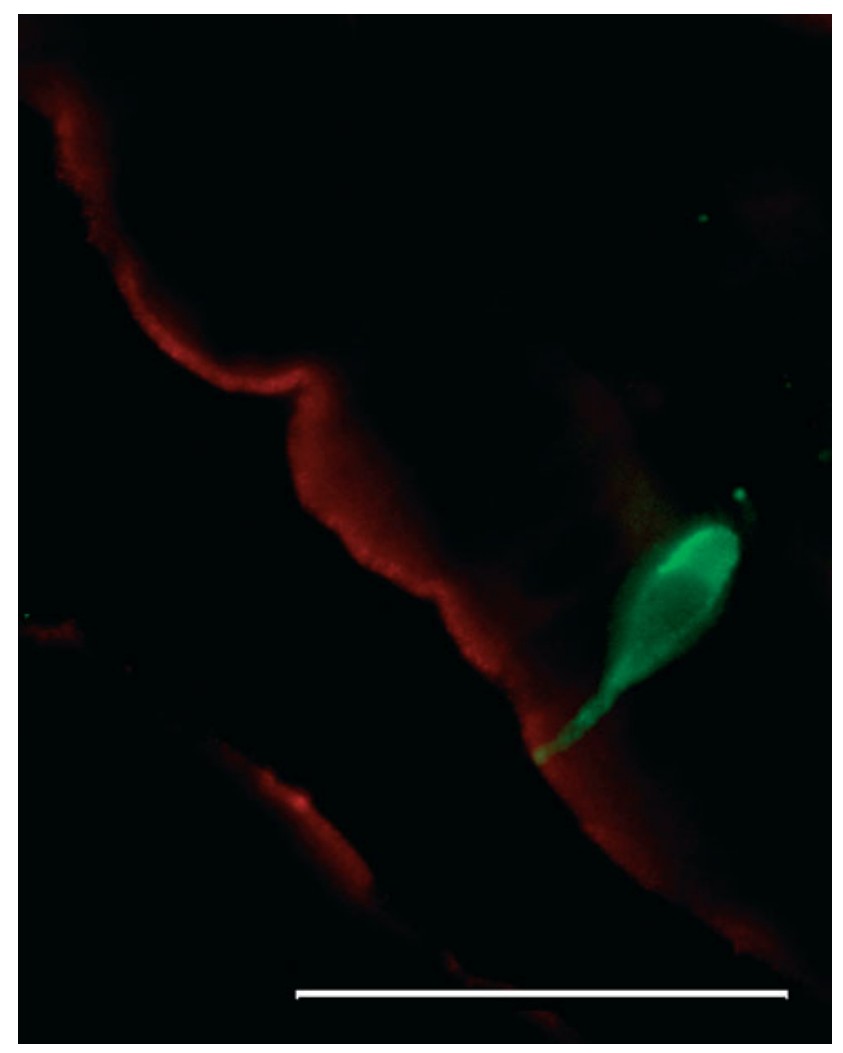

Fig. 2. Expression of $\mathrm{Na}^{+} /$glucose co-transporter 1 (SGLT1) and T1R2 proteins along the crypt-villus axis of swine small intestine. A typical immunoflourescent image showing T1R2 (green) in a subset of cells, and in contrast, SGLT1 (red) is expressed on the luminal membrane of all epithelial cells along the villus. Image is $1000 \times$ magnified. Scale bar represents $10 \mu \mathrm{m}$. 
(a)

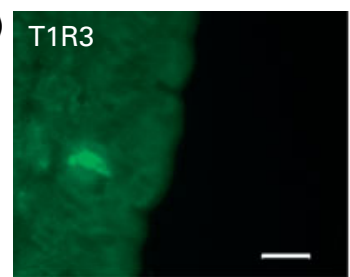

(b)

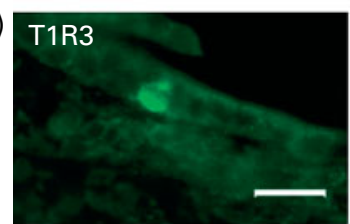

(c) T1R3

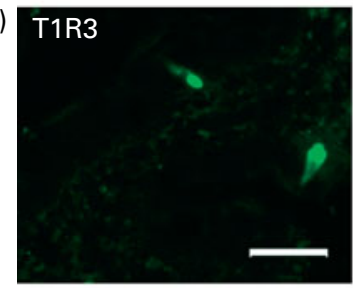

(d)

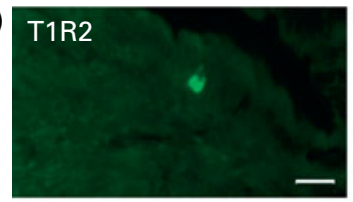

(e)

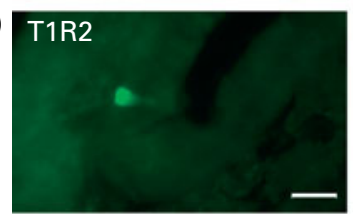

(f)

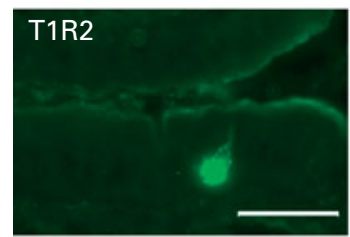

(g) T1R2

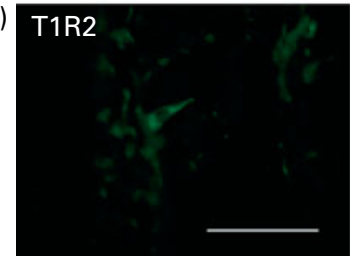

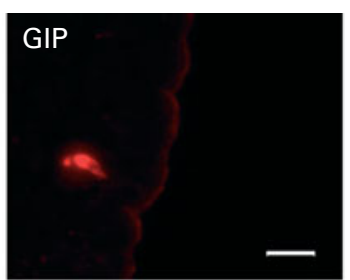
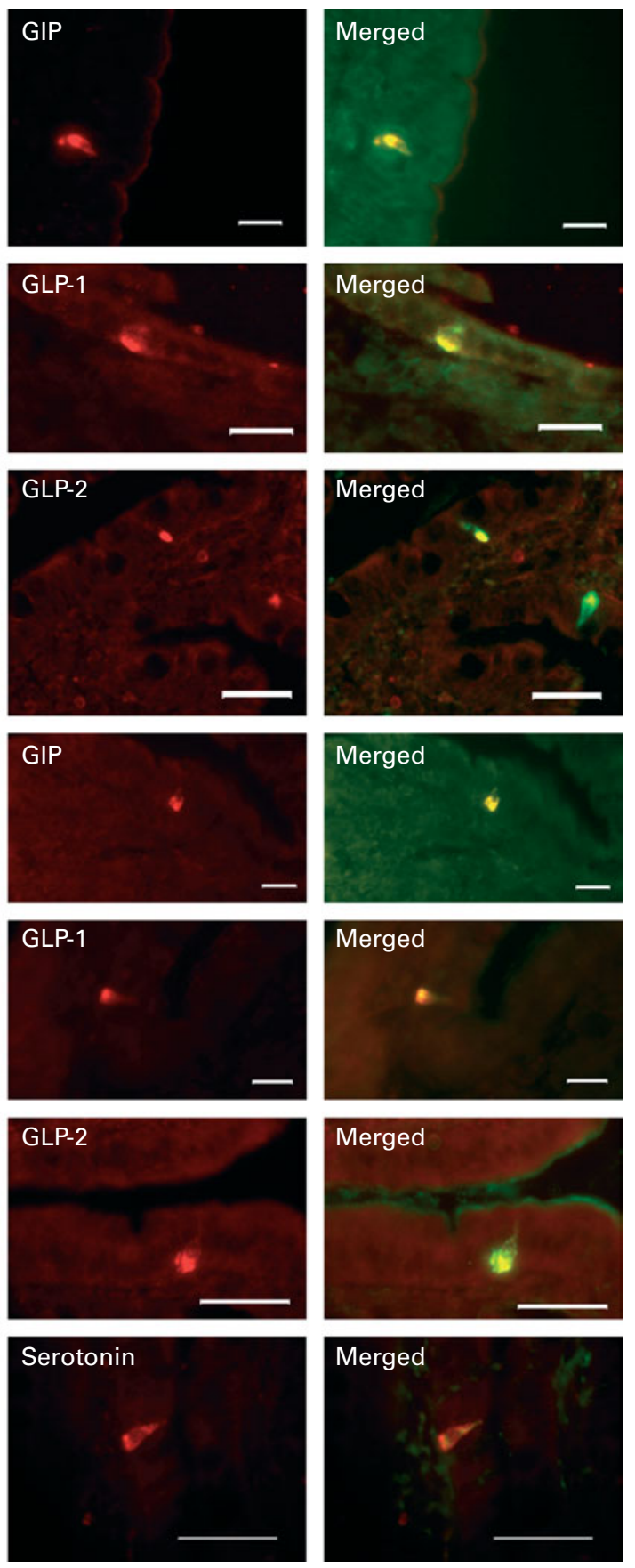
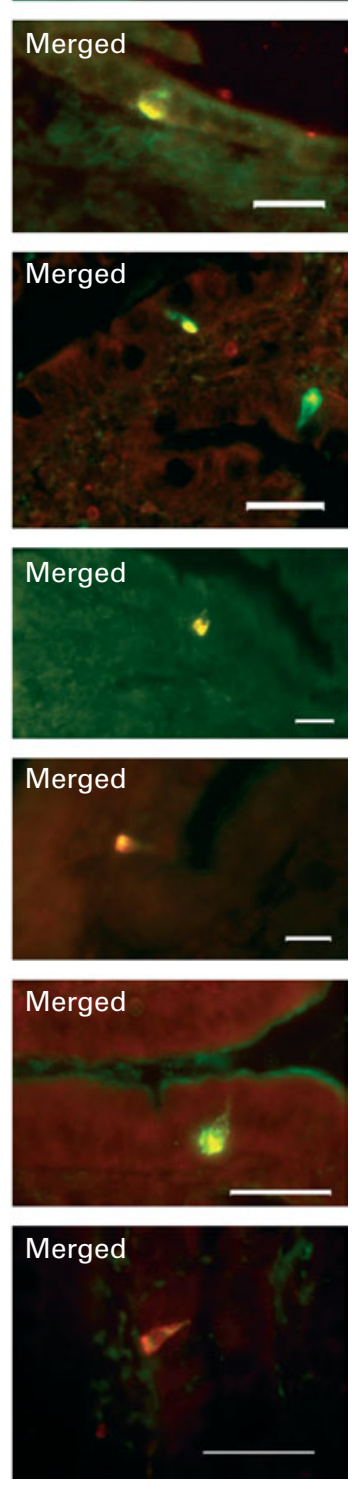

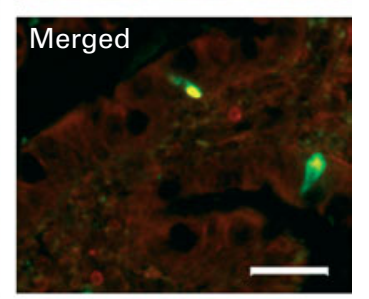

Fig. 3. Detection and localisation of gut hormones and sweet taste receptor subunits T1R2 and T1R3 across crypt-villus axis of swine small intestine. Serial frozen sections of either proximal ((a) and (d)) or mid ((b), (c) and (e)-(g)) small intestine were used for immunofluorescence detection of the sweet taste receptor subunits, T1R2 and T1R3, and the glucose-responsive gut hormones. (a)-(c) T1R3 (green) glucose-dependent insulinotrophic peptide (GIP), glucagon-like peptide (GLP)-1 and GLP-2 (red); (d)-(g) T1R2 (green), GIP, GLP-1, GLP-2 and serotonin (red). Magnification for images (a), (d) and (e) is 200× and that for images (b), (c) and (f) is $400 \times$. Scale bar represents $10 \mu \mathrm{m}$.

Effect of feed supplementation with the artificial sweetener, Sucram, on $\mathrm{Na}^{+} / g$ lucose co-transporter 1 expression

Having shown that the pig intestine expresses the sweet taste receptor, we aimed to determine the effect of feeding artificial sweeteners on SGLT1 expression (Fig. 4). In piglets fed a commercial swine diet containing $43 \%$ CHO supplemented with Sucram, there was a 2 -fold increase $(P=0.001)$ in SGLT1 mRNA abundance in the mid-small intestine compared with that measured in the intestine of piglets fed the diet without Sucram (Fig. 4(a)). There was a correlated 1.6 -fold increase $(P=0.0195)$ in SGLT1 protein abundance (Fig. 4(c) and (d)) and a 1.8-fold increase $(P=0.002)$ in the initial rate of $\mathrm{Na}^{+}$-dependent glucose transport (Fig. 4(b)); both parameters were measured in the same populations of brush-border membrane vesicles. Rates of $\mathrm{Na}^{+}$-dependent D-glucose uptake were 358.7 (SEM 34) and 204.7 (SEM 18.6) pmol/s per mg protein 
(a)

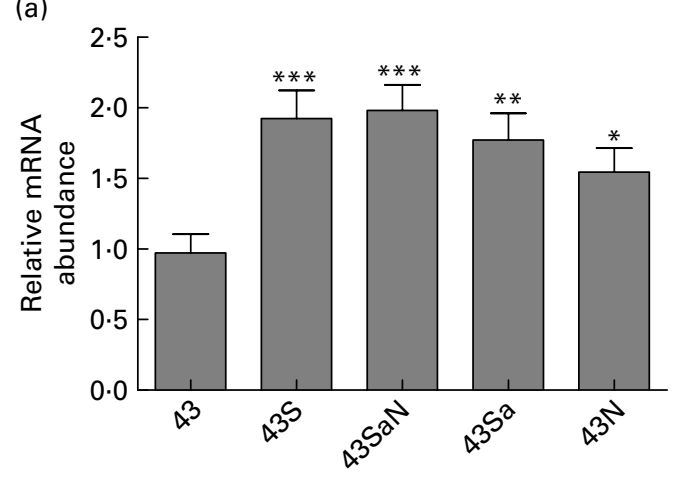

(c)

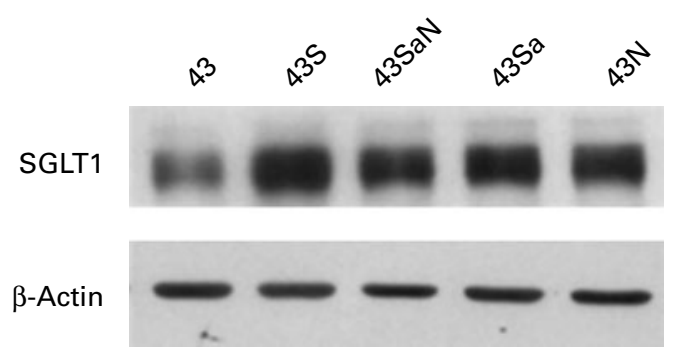

(b)
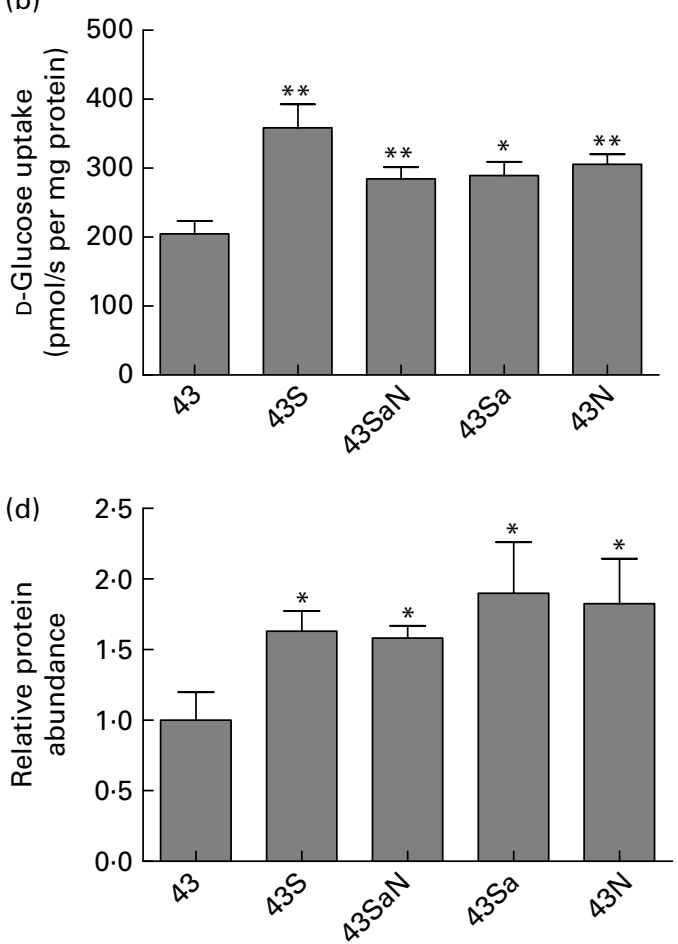

Fig. 4. Expression of $\mathrm{Na}^{+}$/glucose co-transporter 1 (SGLT1) in swine mid-small intestine in response to feed supplementation with the artificial sweeteners, Sucram (43S), saccharin (43Sa), neohesperidin dihydrochalcone (NHDC, 43N) or saccharin and NHDC (43SaN). (a) Steady-state levels of SGLT1 mRNA abundance determined by quantitative PCR were normalised to $\beta$-actin mRNA. (b) Initial rates of $\mathrm{Na}^{+}$-dependent $\mathrm{D}$-glucose uptake into brush-border membrane vesicles (BBMV) measured using a rapid filtration technique. (c) Western blot analysis of SGLT1 and $\beta$-actin protein abundance in BBMV. (d) Densitometric analysis of Western blots normalised SGLT1 protein expression to that of $\beta$-actin. Data were generated in triplicate with $n 6-12$ animals. Results are shown as means with their standard errors. Mean values were significantly different: ${ }^{\star} P<0.05$, ${ }^{\star \star} P<0.01,{ }^{\star \star \star} P<0.001$ (determined using an unpaired Student's $t$ test).

for the $43 \% \mathrm{CHO}$ diet with and without Sucram, respectively (Fig. 4(b)). There were no changes in either villus height or crypt depth in the intestine of piglets maintained on either diet (data not shown). SGLT1 expression was also enhanced in the proximal intestine, but not in the distal intestine of piglets maintained on the diet containing Sucram (data not shown).

Having shown that there is an up-regulation in SGLT1 expression when piglets are fed a diet containing Sucram, we next examined the effect of the constituent sweeteners, saccharin and NHDC, either in combination or separately when included in the drinking-water of piglets. The aims were to determine: (i) whether Sucram when present in the drinking-water has the same effect as when present in the solid food; (ii) the contribution of each sweetener to the magnitude of SGLT1 up-regulation.

In order to include the sweeteners in the drinking-water at concentrations equivalent to the amount present in the feed, we first measured the intake of food and water on a daily basis accurately; this being 0.290 (SD 0.127) kg and 0.688 (SD 0.26) litres/d for each animal ( $n 60$ piglets). The amounts of sodium saccharin and NHDC in Sucram are 120 and $30 \mathrm{mg} / \mathrm{kg}$ of feed, respectively. Therefore, we determined that 0.25 and $0.02 \mathrm{~mm}$ for saccharin and NHDC, respectively, are the concentrations to be included in the drinking-water. The average amounts of sweeteners ingested per day per piglet were 41.19 (SD 2.86), 8.05 (SD 4.33), and 41.73 (SD 5.97) and 5.80 (SD 1.09) mg, respectively, for saccharin, NHDC (included separately), and saccharin and NHDC (introduced in combination) in the drinking-water.

When either (a) saccharin + NHDC, (b) saccharin or (c) NHDC was included in the drinking-water of piglets fed the commercial $43 \% \mathrm{CHO}$ diet, there was a similar increase in SGLT1 expression compared with that measured in the intestine of piglets consuming water without the sweetener (Fig. 4). In the mid-small intestine, SGLT1 mRNA expression was increased 2- $(P=0.001), 1 \cdot 8-(P=0.003)$ and 1.6- $(P=0.016)$ fold for saccharin + NHDC, saccharin and NHDC, respectively (Fig. 4(a)). There were correlated increases in SGLT1 protein abundance, 1.6- $(P=0.035), 1 \cdot 9-(P=0.037), 1 \cdot 8$ $(P=0.040)$ fold (Fig. 4(c) and (d)), and glucose transport (Fig. 4(b)) for all the three dietary regimes. Initial rates of D-glucose uptake were 284.4 (SEM 17), 289.5 (SEM 19.9) and 305.8 (SEM 14.5) $\mathrm{pmol} / \mathrm{s}$ per $\mathrm{mg}$ protein, respectively (Fig. 4(b)).

\section{Quantitative immunofluorescence of $\mathrm{Na}^{+} /$glucose co-transporter 1 abundance along the crypt-villus axis}

SGLT1 protein abundance along the crypt-villus axis of piglet intestine, maintained either on the $43 \% \mathrm{CHO}$ containing commercial diet with Sucram or on the same diet without Sucram, or with saccharine and NHDC in the drinking-water, was measured by quantitative immunofluorescence. The results indicated that in response to the presence of Sucram in the feed or the sweeteners in the drinking-water, there is 
an increase in SGLT1 expression with an average of 1·4-, 1·3and 1.2-fold in the mid, upper and lower regions along the crypt-villus axis, respectively, compared with that measured in the intestine of piglets maintained on the commercial diet only. This increase was also observed in the proximal region, but not in the distal region of the small intestine (data not shown).

\section{Effect of lactisole on $\mathrm{Na}^{+} /$glucose co-transporter 1 expression}

Lactisole, an aralkyl carboxylic acid, inhibits the human sweet taste receptor by binding to the transmembrane domain of human T1R3 ${ }^{(11)}$. It does not inhibit sweet taste perception in mice and rats ${ }^{(11,18)}$. Lactisole, $0.073 \mathrm{~mm}$ (equivalent to 1.47 (SEM $0 \cdot 3) \mathrm{mg} / \mathrm{kg}$ body weight), was included in the drinkingwater of piglets fed the commercial $43 \%$ CHO diet supplemented with Sucram for $3 \mathrm{~d}$. Afterwards, the expression of SGLT1 in the intestinal tissues of piglets was measured at mRNA, protein and functional levels. A typical 2-fold increase in SGLT1 mRNA expression $(P=0.015)$ was observed when piglets were fed the commercial $43 \% \mathrm{CHO}$ diet supplemented with Sucram (Fig. 5(a)) compared with animals that were maintained on the diet without Sucram. This increase was reflected in SGLT1 protein abundance (Fig. 5(b)). However, lactisole that was included in the drinking-water did not inhibit SGLT1 up-regulation by Sucram (Fig. 5(a) and (b)), indicating that lactisole has no inhibitory effect on swine T1R3.

\section{Discussion}

Until recently, the only known mechanism for sensing sugar in the gastrointestinal tract was by the sweet taste receptor located in the taste cells of lingual epithelium ${ }^{(19,20)}$. Sugars and other sweet compounds bind to and activate taste cell G-protein-coupled receptors that couple through the gustatory $\alpha-, \beta$ - and $\gamma$-subunits of the G-protein gustducin to specific second messenger cascades ${ }^{(19-21)}$. T1R include three members (T1R1, T1R2 and T1R3).

Based on heterologous expression of taste receptors and behavioural assays of knockout mice, the combination T1R1 + T1R3 was identified as being responsible for mediating the 'umami' taste of glutamate and L-amino acids, whereas the T1R2 + T1R3 combination was shown to function as broad specificity sweet sensor for natural sugars, sweet proteins and artificial sweeteners ${ }^{(19,20,22-25)}$.

More recent work has revealed that the expression of is not limited to the lingual epithelium. The $\alpha$-subunit of gustducin was shown to be expressed in mouse intestinal endocrine cells and in a murine endocrine cell line ${ }^{(26)}$. Our laboratory was the first to show that T1R family members, T1R1, T1R2 and T1R3, are expressed in mouse and human intestine and in a murine enteroendocrine (stanniocalcin 1) cell line ${ }^{(7)}$. Previous work in our laboratory had indicated that a sugar sensor on the luminal membrane of intestinal epithelial cells is responsible for relaying information on fluctuations in luminal sugar concentration, which leads to changes in SGLT1 expression. Further work in our laboratory demonstrated that sugar-mediated up-regulation of SGLT1 involves a G-protein-coupled second messenger pathway ${ }^{(17)}$.

Convincing evidence for the involvement of the sweet taste receptor and gustducin in intestinal sweet taste transduction was provided by recent studies using mouse knockouts lacking $\alpha$-gustducin or the sweet taste receptor subunit, T1R3 ${ }^{(8,9)}$. Deleting the genes for either $\alpha$-gustducin or T1R3 abolished the ability of mouse intestine to increase SGLT1 expression in response to increased dietary $\mathrm{CHO}$. Furthermore, artificial sweeteners that activate T1R2 + T1R3 in taste cells of the tongue, when included in diet, also increased SGLT1 expression $^{(8)}$. Recent work by Stearns et al. ${ }^{(27)}$ has shown that infusion of saccharin into the lumen of rat small intestine results in a 2-fold increase in SGLT1 expression, indicating that the artificial sweetener is acting directly in the intestine to up-regulate SGLT1 expression.
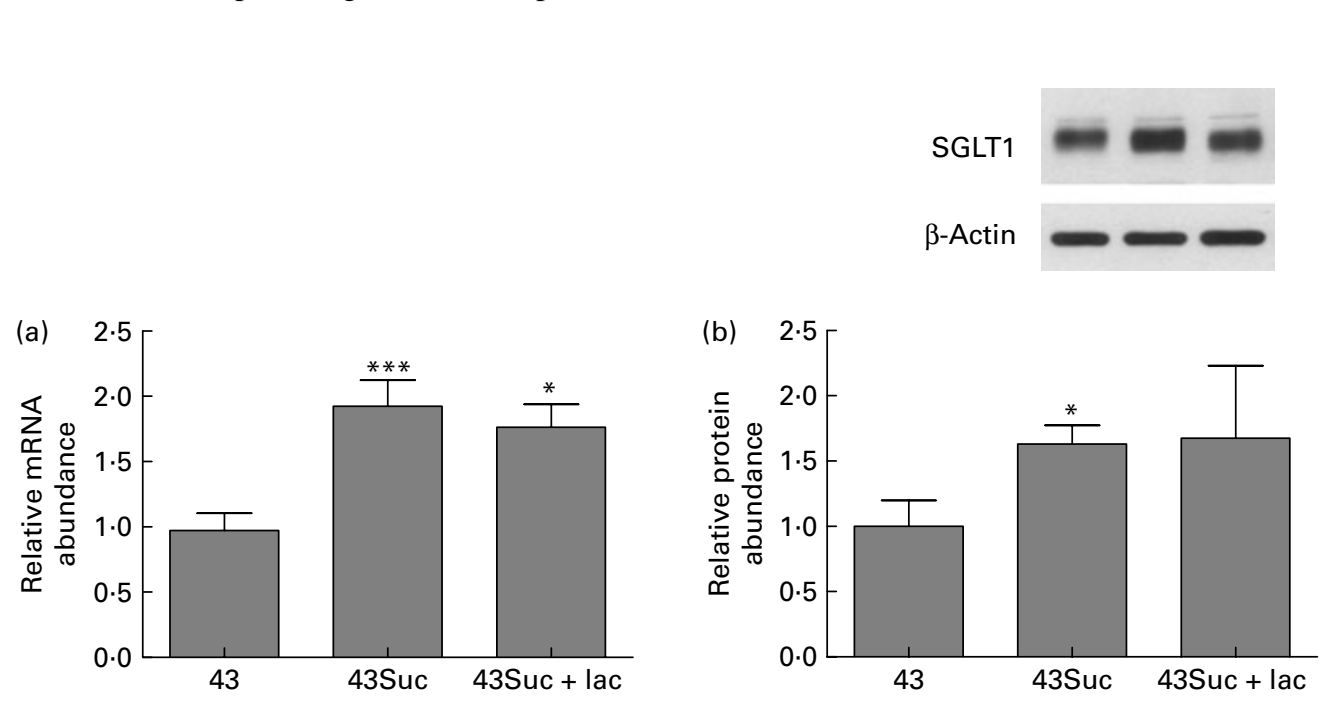

Fig. 5. Lactisole, an inhibitor of human sweet taste receptor, does not inhibit sweetener-induced $\mathrm{Na}^{+} /$glucose co-transporter 1 (SGLT1) up-regulation in swine intestine. Piglets were given a commercial diet containing $43 \%$ carbohydrate (43), the diet supplemented with Sucram without (43Suc) or with 0.073 mm lactisole (43Suc + lac). (a) Steady-state levels of SGLT1 mRNA abundance determined using quantitative PCR were normalised to $\beta$-actin mRNA. SGLT1 and $\beta$-actin proteins from brush-border membrane vesicles isolated from mid-small intestine were detected in Western blots (upper). Densitometric analysis ((b), lower) of Western blots normalised SGLT1 protein expression to that of $\beta$-actin ( $n$ 4-12 animals). Results are shown as means with their standard errors. Mean values were significantly different: ${ }^{\star} P<0.05,{ }^{\star \star *} P<0.001$ (determined using an unpaired Student's $t$ test). 
The artificial sweetener, Sucram, which consists of saccharin and NHDC, is approved for the inclusion in piglets' $\operatorname{diet}^{(5)}$. In one study, it has been shown that piglets consuming a commercial diet containing Sucram do not develop postweaning enteric disorders, and have satisfactory growth compared with those not given Sucram ${ }^{(6)}$.

In the present study, we have shown that the expression of SGLT1 is up-regulated in the intestine of piglets fed diets supplemented with Sucram or when saccharin or NHDC (either alone or in combination) are included in the drinking-water. This implies that sweeteners are effective in enhancing the capacity of the intestine to absorb dietary sugar whether they are included in the feed or provided in a liquid feed, a proposition that has practical applications.

Since we have shown previously that artificial sweeteners act on the intestinal sweet taste receptor to enhance SGLT1

\begin{tabular}{|c|c|c|c|c|c|c|c|c|c|c|c|c|c|c|c|c|c|c|c|c|}
\hline Human T1R3 & 610 & G & $\mathrm{L}$ & V & C & L & G & L & V & C & L & $\mathrm{S}$ & V & $\mathrm{L}$ & $\mathrm{L}$ & $\mathrm{F}$ & $P$ & G & $\mathrm{Q}$ & $\mathrm{P}$ \\
\hline Mouse T1R3 & 615 & $\mathrm{G}$ & $\mathrm{L}$ & I & C & L & G & L & $\mathrm{F}$ & C & $\mathrm{L}$ & $\mathrm{s}$ & $\mathrm{V}$ & $\mathrm{L}$ & L & $\mathrm{F}$ & $P$ & G & $\mathrm{R}$ & $P$ \\
\hline \multirow[t]{4}{*}{ Pig T1R3 } & 608 & $\mathrm{G}$ & $\mathrm{L}$ & $A$ & C & L & G & L & v & C & $\mathrm{L}$ & $\mathrm{s}$ & v & L & L & $F$ & $P$ & G & $\mathrm{R}$ & $\mathrm{P}$ \\
\hline & 630 & $\mathrm{P}$ & $A$ & $\mathrm{R}$ & C & $\mathrm{L}$ & A & 0 & $\mathrm{Q}$ & $P$ & $\mathrm{~L}$ & S & $\mathrm{H}$ & $\mathrm{L}$ & $\mathrm{P}$ & L & $\mathrm{T}$ & G & C & $\mathrm{L}$ \\
\hline & 635 & $S$ & A & $S$ & C & L & A & Q & $\mathrm{Q}$ & $P$ & M & A & $\mathrm{H}$ & L & $\mathrm{P}$ & L & $\mathrm{T}$ & G & $\mathrm{C}$ & $\mathrm{L}$ \\
\hline & 628 & $P$ & A & $\mathrm{S}$ & C & $\mathrm{L}$ & A & Q & $\mathrm{Q}$ & $P$ & $\mathrm{~L}$ & L & $\mathrm{H}$ & L & $P$ & - & $\mathrm{T}$ & $\mathrm{G}$ & C & $\mathrm{L}$ \\
\hline
\end{tabular}

$\begin{array}{lllllllllllllllllllll}650 & \text { T } & \text { L } & \text { F } & \text { L } & \text { Q } & \text { A } & \text { A } & \text { E } & \text { I } & \text { F } & \text { V } & \text { E } & \text { S } & \text { E } & \text { L } & \text { P } & \text { L } & \text { S } & \text { W } & \text { A } \\ 655 & \text { T } & \text { L } & \text { F } & \text { L } & \text { Q } & \text { A } & \text { A } & \text { E } & \text { T } & \text { F } & \text { V } & \text { E } & \text { S } & \text { E } & \text { L } & \text { P } & \text { L } & \text { S } & \text { W } & \text { A } \\ 648 & \text { T } & \text { L } & \text { F } & \text { L } & \text { Q } & \text { A } & \text { A } & \text { E } & \text { I } & \text { F } & \text { A } & \text { R } & \text { S } & \text { E } & \text { L } & \text { P } & \text { P } & \text { S } & \text { W } & \text { A } \\ & & & & & & & & & & & & & & & & & & & & \\ 670 & \text { D } & \text { R } & \text { L } & \text { S } & \text { G } & \text { C } & \text { L } & \text { R } & \text { G } & \text { P } & \text { W } & \text { A } & \text { W } & \text { L } & \text { V } & \text { V } & \text { L } & \text { L } & \text { A } & \text { M } \\ 675 & \text { N } & \text { W } & \text { L } & \text { C } & \text { S } & \text { Y } & \text { L } & \text { R } & \text { G } & \text { L } & \text { W } & \text { A } & \text { W } & \text { L } & \text { V } & \text { V } & \text { L } & \text { L } & \text { A } & \text { T } \\ 668 & \text { D } & \text { W } & \text { L } & \text { C } & \text { S } & \text { H } & \text { L } & \text { W } & \text { G } & \text { P } & \text { W } & \text { A } & \text { W } & \text { L } & \text { A } & \text { V } & \text { L } & \text { L } & \text { A } & \text { M } \\ & & & & & & & & & & & & & & & & & & & & \\ 690 & \text { L } & \text { V } & \text { E } & \text { V } & \text { A } & \text { L } & \text { C } & \text { T } & \text { W } & \text { Y } & \text { L } & \text { V } & \text { A } & \text { F } & \text { P } & \text { P } & \text { E } & \text { V } & \text { V } & \text { T } \\ 695 & \text { F } & \text { V } & \text { E } & \text { A } & \text { A } & \text { L } & \text { C } & \text { A } & \text { W } & \text { Y } & \text { L } & \text { I } & \text { A } & \text { F } & \text { P } & \text { P } & \text { E } & \text { V } & \text { V } & \text { T } \\ 688 & \text { L } & \text { A } & \text { O } & \text { A } & \text { A } & \text { L } & \text { C } & \text { T } & \text { W } & \text { Y } & \text { L } & \text { V } & \text { A } & \text { F } & \text { P } & \text { P } & \text { E } & \text { V } & \text { V } & \text { T } \\ & & & & & & & & & & & & & & & & & & & & \\ 710 & \text { D } & \text { W } & \text { H } & \text { M } & \text { L } & \text { P } & \text { T } & \text { E } & \text { A } & \text { L } & \text { V } & \text { H } & \text { C } & \text { R } & \text { T } & \text { R } & \text { S } & \text { W } & \text { V } & \text { S } \\ 715 & \text { D } & \text { W } & \text { S } & \text { V } & \text { L } & \text { P } & \text { T } & \text { E } & \text { V } & \text { L } & \text { E } & \text { H } & \text { C } & \text { H } & \text { V } & \text { R } & \text { S } & \text { W } & \text { V } & \text { S } \\ 708 & \text { D } & \text { W } & \text { R } & \text { A } & \text { L } & \text { P } & \text { T } & \text { E } & \text { A } & \text { L } & \text { V } & \text { H } & \text { C } & \text { R } & \text { V } & \text { H } & \text { S } & \text { W } & \text { I } & \text { S }\end{array}$

$\begin{array}{lllllllllllllllllllll}730 & \text { F } & \text { G } & \text { L } & \text { A } & \text { H } & \text { A } & \text { T } & \text { N } & \text { A } & \text { T } & \text { L } & \text { A } & \text { F } & \text { L } & \text { C } & \text { F } & \text { L } & \text { G } & \text { T } & \text { F } \\ 735 & \text { L } & \text { G } & \text { L } & \text { V } & \text { H } & \text { I } & \text { T } & \text { N } & \text { A } & \text { M } & \text { L } & \text { A } & \text { F } & \text { L } & \text { C } & \text { F } & \text { L } & \text { G } & \text { T } & \text { F } \\ 728 & \text { F } & \text { S } & \text { L } & \text { V } & \text { H } & \text { A } & \text { A } & \text { N } & \text { A } & \text { T } & \text { L } & \text { A } & \text { F } & \text { L } & \text { C } & \text { F } & \text { L } & \text { G } & \text { T } & \text { F }\end{array}$

$\begin{array}{lllllllllllllllllllll}750 & \text { L } & \text { V } & \text { R } & \text { S } & \text { Q } & \text { P } & \text { G } & \text { R } & \text { Y } & \text { N } & \text { R } & \text { A } & \text { R } & \text { G } & \text { L } & \text { T } & \text { F } & \text { A } & \text { M } & \text { L } \\ 755 & \text { L } & \text { V } & \text { Q } & \text { S } & \text { Q } & \text { P } & \text { G } & \text { R } & \text { Y } & \text { N } & \text { R } & \text { A } & \text { R } & \text { G } & \text { L } & \text { T } & \text { F } & \text { A } & M & \text { L } \\ 748 & \text { L } & \text { V } & \text { Q } & \text { S } & \text { Q } & \text { P } & \text { G } & \text { Y } & \text { H } & \text { N } & \text { S } & \text { A } & \text { R } & \text { S } & \text { L } & \text { T } & \text { F } & \text { A } & \text { M } & \text { L }\end{array}$

$\begin{array}{lllllllllllllllllllllll}770 & \text { A } & \text { Y } & \text { F } & \text { I } & \text { T } & \text { W } & \text { V } & \text { S } & \text { F } & \text { V } & \text { P } & \text { L } & \text { L } & \text { A } & \text { N } & \text { V } & \text { Q } & \text { V } & \text { V } & \text { L } \\ 775 & \text { A } & \text { Y } & \text { F } & \text { I } & \text { T } & \text { W } & \text { V } & \text { S } & \text { F } & \text { V } & \text { P } & \text { L } & \text { L } & \text { A } & \text { N } & \text { V } & \text { Q } & \text { V } & \text { A } & \text { Y } \\ 768 & \text { A } & \text { Y } & \text { F } & \text { I } & \text { T } & \text { W } & \text { V } & \text { S } & \text { F } & \text { V } & \text { P } & \text { L } & \text { L } & \text { A } & \text { N } & \text { V } & \text { P } & \text { V } & \text { A } & \text { S }\end{array}$

$\begin{array}{llllllllllllllllllllll}790 & \text { R } & \text { P } & \text { A } & \text { V } & \text { Q } & \text { M } & \text { G } & \text { A } & \text { L } & \text { L } & \text { L } & \text { C } & \text { V } & \text { L } & \text { G } & \text { I } & \text { L } & \text { A } & \text { A } & F \\ 795 & \text { Q } & \text { P } & \text { A } & \text { V } & \text { Q } & \text { M } & \text { G } & \text { A } & \text { I } & \text { L } & \text { V } & \text { C } & \text { A } & \text { L } & \text { G } & \text { I } & \text { L } & \text { V } & \text { T } & F \\ 788 & \text { Q } & \text { P } & \text { A } & \text { V } & \text { H } & \text { M } & \text { G } & \text { A } & \text { A } & \text { L } & \text { L } & \text { C } & \text { V } & \text { L } & \text { G } & \text { I } & \text { L } & \text { A } & \text { T } & F\end{array}$

Fig. 6. Alignment of sweet taste receptor subunit, T1R3, amino acid sequence of human, mice and pigs. Alignment was determined using Vector NTI (Invitrogen, Paisley, UK). Residues critical for human-specific lactisole inhibition compared with that in mice and pigs are indicated in red. Residues important for neohesperidin dihydrochalcone activation are indicated in green. 
expression in mouse intestine ${ }^{(8,28)}$, we sought to assess if the receptor is expressed in the swine intestine. Using immunohistochemistry, we showed that T1R2, T1R3 and gustducin are expressed in a subpopulation of intestinal cells. Furthermore, the sweet taste receptor subunits and gustducin are coexpressed, confirming their association. However, there are cells containing T1R3 that do not coincide with T1R2 (Fig. 1(a)). This is justified, since T1R3 also participates in amino acid sensing in combination with T1R1. The cells expressing $\mathrm{T} 1 \mathrm{R}$ and gustducin appear triangular or flaskshaped, suggesting that they are of enteroendocrine lineage. Co-expression of the intestinal sweet taste elements with chromogranin A, a classical marker of enteroendocrine cells, confirms the site of expression to be in enteroendocrine cells. The sole location of taste receptors in enteroendocrine cells has also been shown in other $\operatorname{species}^{(8,29)}$. There are, however, chromogranin A-containing cells that do not express gustducin (Fig. 1(d)).

It should be appreciated that enteroendocrine cells constitute $1 \%$ of the cells lining the intestinal epithelium, and yet there are twenty or more subtypes of enteroendocrine cells based on the major products they secrete ${ }^{(30)}$. K-enteroendocrine cells secrete GIP, while L-enteroendocrine cells secrete GLP-1 and GLP-2 in response to dietary CHO or lipids ${ }^{(31,32)}$. There is an aboral decrease in K-cells along the length of the intestine, but an increase in L-cells. Enterochromaffin cells, a subset of enteroendocrine cells, secrete serotonin in response to dietary CHO. The number of enterochromaffin cells increases aborally $^{(33)}$. In the present study, we have shown that in swine small intestine, cells expressing GIP, GLP-1 and GLP-2 also possess the sweet taste receptor subunits T1R2 and T1R3 (Fig. 3(a)-(f)). Moreover, we have demonstrated that some cells possessing the sweet taste receptor also contain serotonin. However, the number of endocrine cells co-expressing T1R and serotonin are far fewer compared with cells possessing T1R with GLP-1, GLP-2 and GIP (10 v. $50 \%$, respectively).

Collectively, the data indicate that $\mathrm{T} 1 \mathrm{R} 2+\mathrm{T} 1 \mathrm{R} 3$ are expressed in $\mathrm{K}$ - and L-enteroendocrine cells and in some enterochromaffin cells. It has been shown that in the intestine, serosal application of GIP and GLP-2 leads to SGLT1 up-regulation $^{(34,35)}$. Furthermore, in response to natural sugars and artificial sweeteners, enteroendocrine cells secrete GLP-1 and GIP through the activation of sweet taste receptor, indicating the involvement of these gut hormones in SGLT1 up-regulation ${ }^{(8,36)}$. Work is underway in our laboratory to determine the types and levels of gut hormones secreted in blood samples removed from piglets maintained either on natural $\mathrm{CHO}$ or on artificial sweeteners.

The digestive physiology of pigs shows great similarities to that of human subjects. However, lactisole, an inhibitor of human T1R3, when included in the drinking-water of piglets had no inhibitory effect on SGLT1 up-regulation (Fig. 5). In contrast, NHDC, an activator of human T1R3, when included in the feed or drinking-water resulted in the enhancement of swine SGLT1 expression. To unravel these findings, we analysed the amino acid sequence of T1R3 in human, mice and pigs (Fig. 6). Jiang et al. ${ }^{(11)}$ have demonstrated by direct mutagenesis that three amino acid residues within human T1R3 (Ala-733, Leu-798 and Arg-790) are critical for humanspecific lactisole sensitivity. Substitution of these residues with the corresponding mouse residues (Val-738, Gln-795 and Ile-803) diminished T1R3 sensitivity ${ }^{(11)}$, thus explaining the insensitivity of mouse T1R3 to lactisole. Sequence analysis (Fig. 6) shows that these three residues are also altered in pig T1R3 (Val-731, Gln-788 and Ala-796) in comparison to human subjects, suggesting that pig T1R3 would also be insensitive to lactisole inhibition. Indeed, our data indicate that there is no inhibitory effect of lactisole on Sucraminduced SGLT1 up-regulation (Fig. 5), demonstrating that pigs, like mice, are insensitive to the inhibitory effects of lactisole.

NHDC is a commercially used sweetener that can activate the human, but not mouse, sweet taste receptor by binding to $\mathrm{T} 1 \mathrm{R} 3^{(37)}$. Winnig et al. $^{(37)}$ have identified seventeen amino acid residues that are important for receptor activation by NHDC. Our data show that the sweet taste receptor in pig intestine is activated by NHDC, as measured by increased SGLT1 expression in response to NHDC included in the diet. Sequence analysis of T1R3 in human subjects, mice and pigs shows that thirteen of the seventeen amino acid residues are conserved across the three species. Of the four remaining residues, one is conserved between human subjects and pigs (hPhe-730 and pPhe-728). In mice, the corresponding residue is Leu-735. It is therefore likely that this is the critical amino acid substitution that prevents the activation of the mouse taste receptor by NHDC in contrast to human and pigs.

We have shown that supplementation of piglets' diet with artificial sweeteners results in enhanced intestinal capacity to absorb glucose with attendant promise of avoiding nutrient malabsorption and enhancing growth and well-being of animals. Such preventative strategies are of particular importance, considering the present restrictions on antibiotic supplementation in the diet and the difficulties in treating post-weaning enteric disorders.

\section{Acknowledgements}

The financial support of Pancosma SA is greatly acknowledged. A. W. M. and E. A. C. are funded by Pancosma SA. M. A. A.-R. is supported through a $\mathrm{PhD}$ awarded by the Republic of Iraq Ministry of Higher Education and Scientific Research. D. K. A. and D. J. B. are funded by PhD fellowships from the Horserace Betting Levy Board and the BBSRC/Pfizer Limited, respectively. We thank Professor D. Iserentant for the provision of lactisole. Authors' contributions are as follows: S. P. S.-B., A. W. M., M. A. A.-R. and K. D. designed the research. A. W. M., M. A. A.-R., D. K. A. and K. D. performed the research; D. J. B., a qualified veterinarian, performed the injection of anaesthetic and assisted in tissue removals; E. A. C. looked after animal maintenance; C. I. and D. B. provided new reagents and advice; S. P. S.-B., A. W. M., M. A. A.-R., D. K. A. and K. D. analysed data; S. P. S.-B. wrote the paper. The authors declare that there is no conflict of interest.

\section{References}

1. Zabielski R, Godlewski MM \& Guilloteau P (2008) Control of development of gastrointestinal system in neonates. J Physiol Pharmacol 59, Suppl. 1, 35-54. 
2. Everts H, van Beers-Schreurs HM \& Vellenga L (1999) Nutrition of young piglets in relation to weaning problems. Tijdschr Diergeneeskd 124, 44-47.

3. Nabuurs MJ (1998) Weaning piglets as a model for studying pathophysiology of diarrhea. Vet $Q \mathbf{2 0}$, Suppl. 3, S42-S45.

4. Nabuurs MJ, Hoogendoorn A \& van Zijderveld-van BA (1996) Effect of supplementary feeding during the sucking period on net absorption from the small intestine of weaned pigs. Res Vet Sci 61, 72-77.

5. Community Register of Feed Additives, pursuant to Regulation (EC) No. 1831/2003, appendices 3 \& 4. http://ec.europa. eu/food/food/animalnutrition/feedadditives/comm_register_feed_ additives_1831-03.pdf

6. Sterk A, Schlegel P, Mul AJ, et al. (2008) Effects of sweeteners on individual feed intake characteristics and performance in group-housed weanling pigs. J Anim Sci 86, 2990-2997.

7. Dyer J, Salmon KS, Zibrik L, et al. (2005) Expression of sweet taste receptors of the T1R family in the intestinal tract and enteroendocrine cells. Biochem Soc Trans 33, 302-305.

8. Margolskee RF, Dyer J, Kokrashvili Z, et al. (2007) T1R3 and gustducin in gut sense sugars to regulate expression of $\mathrm{Na}^{+}$-glucose cotransporter 1. Proc Natl Acad Sci U S A 104, $15075-15080$.

9. PCT application WO2006032693: Intestinal epithelial glucose sensor, Shirazi-Beechey, S \& Dyer, J (publication 30 March 2006 - priority 22 September 2005).

10. Glaser D, Wanner M, Tinti JM, et al. (2000) Gustatory responses of pigs to various natural and artificial compounds known to be sweet in man. Food Chem 68, 375-385.

11. Jiang P, Cui M, Zhao B, et al. (2005) Lactisole interacts with the transmembrane domains of human T1R3 to inhibit sweet taste. J Biol Chem 280, 15238-15246.

12. Shirazi-Beechey SP, Davies AG, Tebbutt K, et al. (1990) Preparation and properties of brush-border membrane vesicles from human small intestine. Gastroenterology 98, 676-685.

13. Moran AW, Al-Rammahi MA, Arora DK, et al. (2010) Expression of $\mathrm{Na}^{+}$/glucose co-transporter 1 (SCLT1) in the intestine of piglets weaned to different concentrations of dietary carbohydrate. Br J Nutr 104, 647-655.

14. Dyer J, Fernandez-Castano ME, Salmon KS, et al. (2002) Molecular characterisation of carbohydrate digestion and absorption in equine small intestine. Equine Vet $J$ 34, 349-358.

15. Dyer J, Hosie KB \& Shirazi-Beechey SP (1997) Nutrient regulation of human intestinal sugar transporter (SGLT1) expression. Gut 41, 56-59.

16. Dyer J, Al-Rammahi M, Waterfall L, et al. (2009) Adaptive response of equine intestinal $\mathrm{Na}^{+} /$glucose co-transporter (SGLT1) to an increase in dietary soluble carbohydrate. Pflugers Arch 458, 419-430.

17. Dyer J, Vayro S, King TP, et al. (2003) Glucose sensing in the intestinal epithelium. Eur J Biochem 270, 3377-3388.

18. Sclafani A \& Perez C (1997) Cypha [propionic acid, 2-(4-methoxyphenol) salt] inhibits sweet taste in humans, but not in rats Physiol Behav 61, 25-29.

19. Kinnamon SC \& Margolskee RF (2008) Taste transduction. In The Senses: A Comprehensive Reference, vol. 4, pp. 219-236 [RR Hoy, GM Shepherd, AI Basbaum, A Kaneko and $\mathrm{G}$ Westheimer, editors]. Amsterdam: Elsevier.
20. Max M \& Meyerhof W (2008) Taste receptors. In The Senses: A Comprehensive Reference, vol. 4, pp. 198-217 [RR Hoy, GM Shepherd, AI Basbaum, A Kaneko and G Westheimer, editors]. Amsterdam: Elsevier.

21. McLaughlin SK, McKinnon PJ \& Margolskee RF (1992) Gustducin is a taste-cell-specific $\mathrm{G}$ protein closely related to the transducins. Nature 357, 563-569.

22. Li X, Staszewski L, Xu H, et al. (2002) Human receptors for sweet and umami taste. Proc Natl Acad Sci U S A 99, 4692-4696.

23. Nelson G, Chandrashekar J, Hoon MA, et al. (2002) An aminoacid taste receptor. Nature 416, 199-202.

24. Montmayeur JP, Liberles SD, Matsunami H, et al. (2001) A candidate taste receptor gene near a sweet taste locus. Nat Neurosci 4, 492-498.

25. Damak S, Rong M, Yasumatsu K, et al. (2003) Detection of sweet and umami taste in the absence of taste receptor T1r3. Science 301, 850-853.

26. Wu SV, Rozengurt N, Yang M, et al. (2002) Expression of bitter taste receptors of the T2R family in the gastrointestinal tract and enteroendocrine STC-1 cells. Proc Natl Acad Sci U S A 99, 2392-2397.

27. Stearns AT, Balakrishnan A \& Rhoads DB, et al. (2010) Rapid upregulation of sodium-glucose transporter SGLT1 in response to intestinal sweet taste stimulation. Ann Surg (In the Press).

28. Dyer J, Daly K, Salmon KS, et al. (2007) Intestinal glucose sensing and regulation of intestinal glucose absorption. Biochem Soc Trans 35, 1191-1194.

29. Sternini C, Anselmi L \& Rozengurt E (2008) Enteroendocrine cells: a site of 'taste' in gastrointestinal chemosensing. Curr Opin Endocrinol Diabetes Obes 15, 73-78.

30. Rehfeld JF (1998) The new biology of gastrointestinal hormones. Physiol Rev 78, 1087-1108.

31. Elliott RM, Morgan LM, Tredger JA, et al. (1993) Glucagon-like peptide-1 (7-36)amide and glucose-dependent insulinotropic polypeptide secretion in response to nutrient ingestion in man: acute post-prandial and 24-h secretion patterns. $J$ Endocrinol 138, 159-166.

32. Ponter AA, Salter DN, Morgan LM, et al. (1991) The effect of energy source and feeding level on the hormones of the entero-insular axis and plasma glucose in the growing pig. Br J Nutr 66, 187-197.

33. Sjolund K, Sanden G, Hakanson R, et al. (1983) Endocrine cells in human intestine: an immunocytochemical study. Gastroenterology 85, 1120-1130.

34. Singh SK, Bartoo AC, Krishnan S, et al. (2008) Glucose-dependent insulinotropic polypeptide (GIP) stimulates transepithelial glucose transport. Obesity (Silver Spring) 16, 2412-2416.

35. Cheeseman CI (1997) Upregulation of SGLT-1 transport activity in rat jejunum induced by GLP-2 infusion in vivo. Am J Physiol 273, R1965-R1971.

36. Jang HJ, Kokrashvili Z, Theodorakis MJ, et al. (2007) Gut-expressed gustducin and taste receptors regulate secretion of glucagon-like peptide-1. Proc Natl Acad Sci U S A 104, 15069-15074.

37. Winnig M, Bufe B \& Meyerhof W (2005) Valine 738 and lysine 735 in the fifth transmembrane domain of rTas1r3 mediate insensitivity towards lactisole of the rat sweet taste receptor. BMC Neurosci 6, 22. 